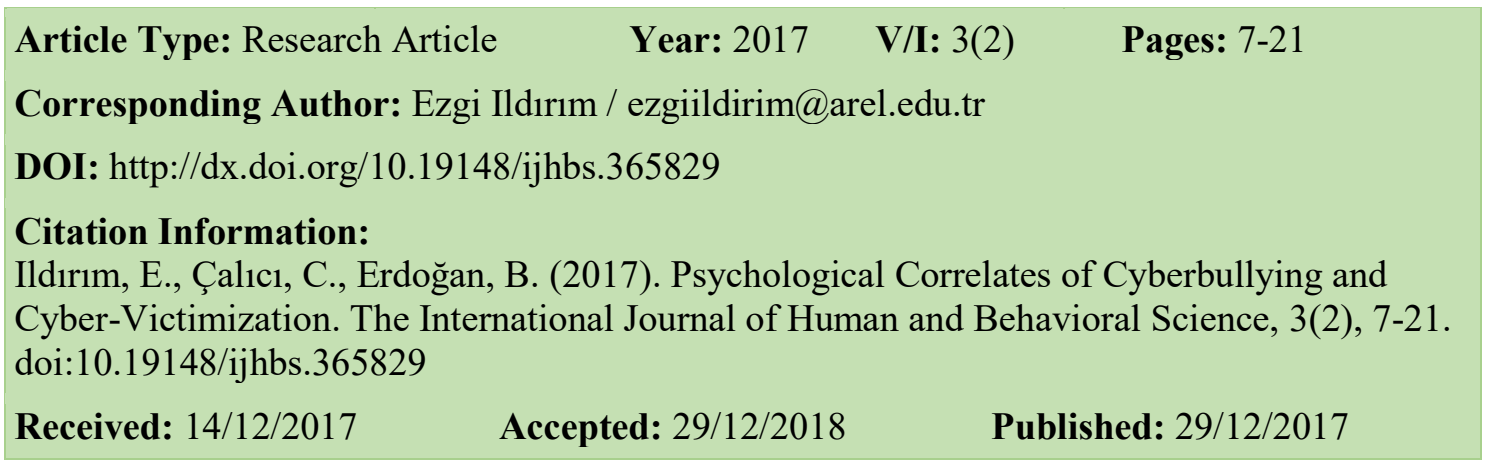

\title{
Psychological Correlates of Cyberbullying and Cyber-Victimization
}

Ezgi Ildırım, Istanbul University,Institute of Forensic Medicine, Turkey ORCID: https://orcid.org/0000-0002-0805-6506

Can Çalıcı, Istanbul University,Institute of Forensic Medicine, Turkey ORCID: https://orcid.org/0000-0001-9145-681X

Barışhan Erdoğan, Istanbul Arel University, Turkey ORCID: https://orcid.org/0000-0003-2648-0914

\begin{abstract}
Technology use is increasing rapidly in today's world. Technological advances created new medium for aggression. Cyber bullying is one type of these behaviors which is defined as bullying via electronic communication tools. Although bullying is not an old issue, cyber bullying is a new concept which has similarities and differences between bullying in real life. Researchers found that cyber bullying and victimization have psycho-social correlates. This research aims to investigate cyberbullying and victimization along with their relationship with anxiety, depression, hostility, negative self-concept, impulsivity, empathy and internet addiction. The sample consists of 198 university students between 18 and 25 years of age. $65 \%$ of participants are female and the other $35 \%$ are male. In this study, The Turkish version of Short Symptom Inventory is used to measure depression, anxiety, somatization, hostility and negative self-concept. The Barratt Impulsivity Scale is used to measure impulsiveness and Basic Empathy Scale is used to measure empathy. Both cyberbullying and cyber victimization positively correlate with anxiety, depression, somatization, hostility, impulsivity and internet addiction. On the contrary, cyber bullying negatively correlated with empathy. As a result, it was concluded that cyberbullying and cyber victimization go hand in hand. The results showed that both variables show similar correlations with same psychological aspects.
\end{abstract}

Keywords: cyberbullying, cyber victimization, impulsivity, empathy, internet addiction

\section{Introduction}

Cyberbullying was first used by Bill Belsey as a new concept of bullying (Belsey, 2004). Ybarra and Mitchell (2004) considered the concept of online harassment as a form of cyber aggression instead of cyberbullying. In a similar way, Willard (2007) defines offline social aggression as a reflection on online.

In addition to the conceptual definition of cyberbullying, it is possible to talk about the components of the phenomenon. As well as having components such as intent, repetition, power inequality of traditional bullying, cyber bullying has different components that are anonymity and publicity (Bauman et al., 2013). As a result of a study carried out in Australia among adolescents, it has been emphasized that cyberbullies commonly manifest their behaviors in two forms which may be covert or explicit (Spears et al., 2009). Nocentini and others (2010) have categorized the cyber bullying behavior into four main themes. According to their classification, these behaviors are oral and written behaviors (text messages, phone calls, chat, blogs, social networks, etc.), visual behaviors (inappropriate visual content, video and photo sharing), exclusion (excluding a 
person from online channels) and disclosure (online sharing of personal information of someone without their consent etc.).

As cyberbullying has been becoming a major issue, differences between traditional bullying and cyber bullying come forward. Researchers started to study on cyberbullying and victimization concepts for intervention and prevention. Today results showed that cyberbullying behavior is a complex structure which is associated with various factors. Researchers have found that cyberbullying is associated with alcohol use, delinquent behavior, depression, low self-esteem, relational aggression, peer rejection, and acceptance of aggression. Besides according to recent studies losing emotional traits, excessive exposure to violent images and media, playing violent video games, have all been related with cyberbullying (Lianos, 2017). As it was stated, most of these factors are psychological concepts such as anxiety, depression, somatization, hostility, empathy, impulsivity and internet addiction.

\subsection{Anxiety}

Anxiety, which may be described as an unpleasant affective state, is one of the problems from which both bullies and victims may suffer (Roy-Byrnr, 2004, p.70; Craig, 1998). Kowalski and Limber (2013) showed that both traditional and cyber victimization correlated with anxiety; likewise a positive correlation was also found for bullies. Meta-analysis results also supported that cyber victims are more likely to suffer from anxiety compared to others who were not bullied (Kowalski, Giuretti, Schroeder \& Lattanner, 2014). Besides studies conducted in different cultures also showed that victims are more likely to suffer from anxiety (Price, Chin, HigaMcMillan, Kim \& Frueh, 2013; Çetin, Eroğlu, Peker, Akbab \& Pepsoy, 2012; Aoyama, Saxon \& Fearon, 2011; Tomşa, Jenaro, Campbell \& Neacşu, 2013). Although there is currently a small number of research on the underlying mechanism of anxiety resulting from cyberbullying, the number has been increasing for a better comprehension of the issue. One of these research results showed that coping strategies against cyberbullying is one of the predictors of anxiety. Avoidance coping strategies such as internalizing and externalizing are more likely to result in anxiety due to cyber victimization (Na, Dancy \& Park, 2015).

\subsection{Depression}

Studies suggest that cyber victims are more likely to suffer from internalization problems like anxiety. Depression is another internalizing disorder which has proved to be connected with cyberbullying and victimization (Bonanno \& Hymel, 2013). The effects of cyberbullying have been examined in the context of mental health of adolescents mostly based upon their tendency of internalizing the problems within an extensive network of communication. Former studies showed that cyberbullying victims are more likely to develop mood disorders; Wigderson and Lynch (2013), Klomek, Marrocco, Kleinman, Schonfeld and Gould (2007) are among the first researchers to discover a significant correlation between depression and cyberbullying victimization in adolescence. Even though face-to-face bullying also generates some negative reactions such as helplessness, loneliness and sadness in the victims, cyberbullying knows no limits. Its victims are attacked in their own houses and rooms which they conceptualize as the safest places in their daily lives and the attackers are mostly unknown (Bauman, 2014) to them. The study of Hinduja and Patchin (2010) demonstrates that middle school students with a cyberbullying experience whether as a victim or a perpetrator, think about or attempt suicide more frequently compared to their peers.

Research on traditional and cyberbullying showed that victims of cyberbullying are more likely to report depression compared to traditional bullying victims (Tennant, Demaray, Caoyle \& Molecki, 2015). 


\subsection{Somatization}

Somatization is the physical manifestation of psychological problems and it highly correlates with anxiety and depression. Therefore, like depression and anxiety, somatization is also one of the psychological correlates of cyberbullying (Koh, 2013). Previous studies found that both cyberbullies and victims as well as traditional bullying victims showed psychosomatic symptoms like headaches, sleep problems and abdominal pain (Fekkes, Pijpers, Verloove-Vanharick, 2004).

Though limited in number, there are studies that consider cyberbullying along with its somatic manifestations from the points of both the victim and the perpetrator. Kowalski and Limber (2013) demonstrated that cyberbullying has some psychosomatic consequences such as sleep disorders, headache, poor appetite and skin problems as well as psychological effects. Apart from headache, poor appetite and disorganized sleeping schedule that are in accordance with the depressive mood created by the cyberbullying experience, skin conditions are particularly striking especially from the psychoanalytical point of view. Anzieu (1974) was the first psychoanalyst to describe the skin as an organ that not only serves as a boundary between the inner and outer realities of an individual, but also becomes the very first channel of communication between the baby and mother or caregiver. The term "The Skin-Ego" was formed by Anzieu based upon this crucial mission of skin as an envelope that covers the self, and has been introduced to the psychoanalytical literature. It becomes more meaningful that skin is one of the first channels on which the primary physical manifestations are found and it is affected in the first place by the external threat when the position of it as a border between the individual and the others is taken into consideration.

Somatization is not only a consequence of cyberbullying but it was also found to be a predictor of cyberbullying. Arıcak (2009) showed that somatization is one of the significant predictors of future cyberbullying behavior like hostility and psychoticism.

\subsection{Hostility}

Similar to somatization, depression and anxiety are correlated and interact with hostility. Besides, hostility and anger are also associated with somatization. Hostility is considered as a general trait which consists of behavioral, cognitive and affective components. Cognitive component involves negative beliefs and attitudes like devaluation of others, mistrust, desire of hurting others (Miller, Smith, Turner, Guijarro \& Hallet, 1996).

Hostility is one of the variables that is correlated with cyberbullying and victims owning to the fact that cyberbullying is defined as hostile behavior toward others (Tokunaga, 2010). Like traditional bullies who show verbal and physical aggressiveness and revenge seeking behaviors (Hazler, Carney, Green, Powell \& Jolly, 1997), recent studies indicate that cyberbullying behavior is related to aggression and anger (Patchin \& Hinduja, 2006; Ybarra, Espelage \& Mitchell, 2007). In addition, rule breaking behaviors also correlate positively.

Hostility was found to be both a predictor (Arıcak, 2009) and consequence of cyberbullying behavior. Studies show that some cyberbullying victims can report hostility especially towards the cyberbully and audience of the bullying behavior (Şahin, San, Özer, Er, 2010; Topçu, 2008). Another research, that focused on hostile sexism in relationships, indicate that male participants' hostile sexism is related to cyberbullying their girlfriends (Martinez-Pecino \& Duran, 2016).

\subsection{Negative Self Concept}

Self-concept is defined as one's perception and evaluation of themselves. Negative self-concept is found to be correlated with depressive symptoms (Tarlow \& Haaga, 1996). Traditional bullying victims showed higher degree of negative self-evaluation compared to non-victims (Solberg \& Olwens, 2003). On the other hand, a study conducted among Irish schools showed traditional 
bullies have lower self-concepts compared to cyberbullies (Corcoran, Connolly \& O'Moore, 2012).

Another study, however, shows that cyberbullying is associated with negative self-concept (Zezulka, Seigfried- Spellar, 2006). For instance friend networking sites play a crucial role in social self-esteem of users. Negative feedbacks indirectly affect users' self-esteem by decreasing it (Valkenburg, Peter \& Schauten, 2006). Another confirming research showed that chatroom victims found to have a lower degree of self-esteem. Besides students with lower self-esteem are more likely to suffer from chatroom bullying (Katzer, Fetchenhauer \& Belschak, 2009).

\subsection{Impulsivity}

Impulsivity is one the variables that are frequently connected with anger and hostility. Pabian and Vankelbosch Model (2014) shows that interaction of anger and impulsivity contributes to cyberbullying. Although there are many researches on impulsivity and traditional bullying, little is known about the relationship between cyberbullying and impulsivity.

For that reason impulsivity among cyberbullies are one of the crucial notions that require future researches. It is assumed that the anonymity and deindividuation along with the easier objectification of the victim due to the fact that the perpetrator and the victim are not physically together, lead to violent impulsive behavior (McKenna \& Bargh, 2000). The desire for power and control, impulsivity and dominance used to describe face-to-face bullies, are also valid for cyberbullies (Campfield, 2008). A longitudinal study conducted with children shows that impulsivity predicted cyberbullying behavior after one year (Fanti, Demetriou \& Hawa, 2012). Impulsivity also plays a significant role in bystanders help behavior. Another study on bystanders shows that less impulsive students are more likely to help cyberbullying victims (Erreygers, Pabian, Vandebosch \& Baillien, 2016).

\subsection{Internet Addiction}

Internet addiction, which was introduced in 1996 by Kimberly Young, is one of the behavioral addictions. Studies in an increasing number demonstrate that similar to other addictions, internet addicts are also preoccupied with use; continue to use despite harm, tolerance, unsuccessful efforts to control or cut down use (Young, 2004). Literature shows that internet addiction is related to physical complaints, depression, school problems, relationship problems and loneliness (Chen \& Peng, 2008; Young, 2004). Although it is not included in DSM 5, it is considered as one of the major problems especially for the young (Ahn, 2007).

According to recent studies, internet addiction is one of the most common types of addiction to such a degree that it was measured to affect $15 \%$ of the population (Block, 2008; Bakken et al., 2009). Online sexual acts and following pornographic websites are thought to be directly correlated with this type of addiction (Gönül, 2002).

Cyber bullying and internet use relation is pointed out by researchers (Topçu, 2008; Navarro, Serna, Martínez \& Ruiz-Oliva, 2013). Internet addiction and problematic use are related with cyberbullying (Chang et al, 2015). Some studies found that internet addiction is a predictor of cyberbullying.

\subsection{Empathy}

Empathy is a complex construct which is defined as understanding other people's feelings. As a multidimensional construct, however, empathy also means imagining another's feelings and projecting yourself into his/her reaction (Batson, 2009). Empathy consists of two crucial constructs which are affective empathy and cognitive empathy. Affective empathy involves experiencing other people's feelings whereas understanding others' feelings is defined as cognitive empathy (van Noorden, Haselager, Cillessen \& Bukowski, 2014). 
Today, the relation between empathy and aggression is incontrovertible as it was proven by many researches. Due in no small part to that reason, many intervention and prevention programs on bullying also include empathy trainings (Farrington \& Ttofi, 2009). Studies demonstrate that there is a negative correlation between empathy and aggressive and antisocial behavior whereas it is positively related to prosocial behaviors (Strayer \& Roberts, 2004; Richardson, Hammock, Smith, Gardner \& Signo, 1994).

Cyberbullies are found to be less empathic than their non-cyberbully counterparts. A research conducted for modeling predictors and consequences of cyberbullying found that empathy is one of the predictors. Although another study conducted in Singapore showed that cognitive empathy plays a crucial role in cyberbullying behavior, it also found that both cognitive and affective empathy play a vital role on cyberbullying (Ang \& Goh, 2010).

Empathy is also found to be related to bystander behavior. Research showed that both types of empathy cause a decrease in negative bystander behavior against cyberbullying (Barlińska, Szuter \& Winiewsky, 2012).

\subsection{Current Study}

Cyber form of bullying and victimization is a growing problem as the number of bullies, victims and bystanders is increasing every day. The number of studies on this subject is accordingly increasing at a fast pace. Authors from different areas with different perspectives contribute to the literature. As cyberbullying and victimization is a complex construct correlated with various factors, these are still being investigated especially for the university students population over 18 years of age.

As it's pointed out above; the duration of being online and excessive internet use, directly and indirectly, affect the exposure to cyberbullying as a victim or bully. On the other hand, several possible consequences may include lack of sufficient sleep, having psychosomatic problems, depression and anxiety caused by increased amount of the time spent online.

For that reason this study aims to expand the literature on cyberbullying and cyber victimization from the perspective of psychology by examining seven different variables' correlation with cyberbullying and victimization in one sample. Besides there are few researches on the relation between impulsivity, internet addiction and cyberbullying in the Turkish university sample. This study hypothesises that:

$\mathrm{H}_{1}$ : There is a positive correlation between cyberbullying and anxiety.

$\mathrm{H}_{2}$ : There is a positive correlation between cyberbullying and depression.

$\mathrm{H}_{3}$ : There is a positive correlation between cyberbullying and somatization.

$\mathrm{H}_{4}$ : There is a positive correlation between cyberbullying and hostility.

$\mathrm{H}_{5}$ : There is a positive correlation between cyberbullying and impulsivity.

$\mathrm{H}_{6}$ : There is a positive correlation between cyberbullying and internet addiction.

$\mathrm{H}_{7}$ : There is a positive correlation between cyberbullying and empathy.

\section{Method}

\subsection{Sample}

Sample consists of 198 volunteered undergraduate students of Istanbul Arel University. 65\% of the participants are female and $35 \%$ are male; that is to say 120 females and 64 males participated in the research. Snowball sampling is used as randomly chosen psychology students and their friends on the campus have participated. Participants' age range is between 18 and 25 with mean 20.8 . 


\subsection{Instruments}

Present research used five scales for measuring variables. Cyberbullying Scale was developed by Çetin and colleagues to assess cyber victimization and bullying. Turkish version of the Short Symptom Inventory is used to measure depression, anxiety, somatization and hostility. The Barratt Impulsivity Scale is used to measure impulsiveness. Basic Empathy Scale is used to measure empathy. Addiction Profile Index Internet Addiction form is used to measure internet addiction.

\subsubsection{Cyberbullying and Cybervictimization Scale}

Cyber Victimization and Bullying Inventory was developed by Çetin, Yaman and Peker (2011). The inventory is a self-reported 22 items, five-point Likert Scale. Same items are used for both victimization and bullying. Victimization part consists of 22 items phrased as 'I exposed...' whereas bullying part consists of the same 22 items phrased as 'I exhibit...'. Reliability and validity analyses were conducted for both two scales.

The inventory has three factors that were named as cyber verbal bullying, hiding identity and cyber forgery. Confirmatory factor analysis supported the three factor model. Reliability analysis showed that for cyber victimization scale internal consistency coefficient is .89 , split half reliability is .79 and test re-test realiability is .85 . Cyberbullying scale internal consistency coefficient, split half reliability and test re-test reliability were found to be $.89, .79$ and .90 respectively.

\subsubsection{Brief Symptom Inventory}

Original form was developed by Derogatis as a 53 items, five-point Likert Scale questionnaire with nine subscales. Turkish adaptation was conducted by Şahin and Durak (1994) on university students. In Turkish form factors decreased to five which are depression, anxiety, somatization, hostility and negative self-concept by screen test. Cronbach alpha values for subscales change between .63 and .86 . Cronbach alpha is found to be .96 for the whole scale.

\subsubsection{Baratt Impulsivity Scale-11}

Original scale was developed by Patton, Stanford and Barratt. Turkish version of Baratt Impulsivity Scale- 11 was adopted to Turkish by Güleç et al. (2008). The scale consists of 30 items which are 4-point Likert scale. Cronbach's alpha coefficient for the total scale is found to be 0.78 for undergraduate students. Test-retest correlation is found to be 0.83 . An exploratory principal-components analysis found primary six factor which form three second-order factors which are attentional impulsiveness, motor impulsiveness and non-planning impulsiveness. Turkish adaptation of the scale shows a correlation between the Aggression Questionnaire, Eysenck Personlity Questionnaire, Spielberger State-Trait Anger Expression Inventory.

\subsubsection{Basic Empathy Scale}

Original scale was developed by Jolliffe and Farrington. The scale consists of twenty items, 5point-Likert. Turkish version of the scale was adopted by Topçu, Erdur-Baker and Çapa-Aydın. Confirmatory factor analysis found a two factors model with GFI value .90, AGFI is .87, RMSEA value .60. Cronbach alpha coefficient was found to be $.80, .76$ and .79 for cognitive empathy, emotional empathy and for whole scale respectively. Turkish version of the scale negatively correlated with Cyberbullying Inventory and Traditional Bullying Questionnaire (Topcu et al, 2016).

\subsubsection{Addiction Profile Index Internet Addiction Form}

Addiction Profile Index Internet Addiction Form (APIINT) is developed by Ögel, Evren, Karadağ and Gürol (2012) as 18 questions, 5-point Likert Scale. APIINT consists of five dimensions which are frequency of internet use, diagnostic criteria of addiction, impact of internet use on life, craving for internet use and motivation to reduce internet use. Cronbach alpha coefficient was 
found to be differ between 0.64 and 0.77 for sub dimension. For the whole scale Cronbach alpha coefficient was calculated as 0.88 . Reliability study results for item total correlation was found to be between 0.44 and 0.68 . Test retest validity is 0.85 .

Explanatory factor analysis showed that factor loads for sub dimensions are $0.88,0.84,0.80,0.62$ and 0.61 for diagnostic criteria, impact on life, craving, internet use characteristics and motivation respectively (Ogel, Karadag, Satgan \& Koç, 2015).

\subsection{Data Analysis}

SPSS 21.0 was used to conduct the analyses. Normality and linearity analysis showed that data did not satisfy assumptions for parametric tests. For that reason; Mann Whitney U which is a nonparametric statistical analysis is used for comparison of cyberbullying and victimization with regarded to gender. Spearman Rho is used for correlation.

\section{Findings}

There is a significant gender difference for cyberbullying. From data results, it can be concluded that male participants $(M d n=32.5)$ showed significantly higher involvement in cyberbullying than female counterparts $(M d n=24), U=2416.5, \mathrm{p}=.000, \mathrm{r}=-.310$. Likewise males $(M d n=$ 29.5 ) have a significantly higher risk of being victims of cyberbullying compared to females ( $M d n$ =26), $U=2975.0, \mathrm{p}=.004, \mathrm{r}=-.192$.

Research results showed that cyber victimization had a weak positive correlation with sub-factors of Brief Symptom Inventory which are anxiety $(r=.374, p<.01)$, depression $(r=.298, p<.01)$, somatization $(\mathrm{r}=.300, \mathrm{p}<.01)$ and hostility $(\mathrm{r}=.310, \mathrm{p}<.01)$. Likewise cyberbullying positively correlated with anxiety $(\mathrm{r}=.254, \mathrm{p}<.05)$, depression $(\mathrm{r}=.171, \mathrm{p}<.05)$, somatization $(\mathrm{r}=.174$, $\mathrm{p}<.05)$ and hostility $(\mathrm{r}=.262, \mathrm{p}<.01)($ Table 1$)$.

Table 1: Correlation Between Cyberbullying, Victimization and BSI Subscales

\begin{tabular}{|c|c|c|c|c|c|}
\hline & Anxiety & Depression & Somatisation & Hostility & $\begin{array}{l}\text { Negative } \\
\text { Self Concept }\end{array}$ \\
\hline Cyberbullying & $.254^{*}$ & $.171 * *$ & $.174 * *$ & $.262 * *$ & $.276 * *$ \\
\hline $\begin{array}{l}\text { Cyber } \\
\text { Victimization }\end{array}$ & $.374 * *$ & $.298 * *$ & $.300 * *$ & $.310 * *$ & $.418^{* *}$ \\
\hline
\end{tabular}

${ }^{*} \mathrm{p}<.05$, two tailed. ${ }^{* *} \mathrm{p}<.01$, two tailed.

Empathy and bullying relation was also tested through statistical analyses. Cognitive empathy showed negative correlation between cyberbullying $(\mathrm{r}=-.278, \mathrm{p}<.01)$ and cyber victimization $(\mathrm{r}=-.175, \mathrm{p}<.05)$. Similarly there was a weak negative significant correlation between cyberbullying and affective empathy $(\mathrm{r}=-.321, \mathrm{p}<.01)$. Likewise cyber victimization and affective empathy also negatively correlated $(\mathrm{r}=-.220, \mathrm{p}<.05)$.

Table 2: Correlation between cyberbullying, victimization and empathy

\begin{tabular}{lll} 
& Cognitive Empathy & Affective Empathy \\
\hline Cyberbullying & $-.278^{* *}$ & $-.321^{* *}$ \\
Cyber Victimization & $-.175^{*}$ & $-.220^{*}$
\end{tabular}

$* \mathrm{p}<.05$, two tailed. $* * \mathrm{p}<.01$, two tailed. 
All subscales of impulsivity correlated with cyberbullying and victimization. Motor impulsivity showed a higher correlation among other subscales. Analysis results showed that there is a positive correlation between cyberbullying and motor impulsivity $(\mathrm{r}=.391, \mathrm{p}<.05)$. Moreover cyber victimization and motor impulsivity positively correlated $(\mathrm{r}=.334, \mathrm{p}<.05)($ Table 3$)$.

Table 3. Correlation between cyberbullying, victimization and impulsivity

\begin{tabular}{lcccc} 
& Attention & Motor & Non Planning & $\begin{array}{l}\text { Impulsivity } \\
\text { Total }\end{array}$ \\
\hline Cyberbullying & $.254^{* *}$ & $.391^{* *}$ & $.160^{*}$ & $.359 * *$ \\
Cyber Victimization & $.205^{*}$ & $.334^{* *}$ & $.051^{*}$ & $.307 * *$ \\
\hline$* \mathrm{p}<.05$, two tailed. $* * \mathrm{p}<.01$, two tailed. & &
\end{tabular}

Internet addiction subscales positively correlated with cyberbullying. Internet addiction subscales and cyber victimization positively correlated except for the frequency subscale. A higher correlation was found between internet's impact on one's life and cyberbullying $(\mathrm{r}=.455, \mathrm{p}<$ .01) (Table 4).

Table 4. Correlation between cyberbullying, victimization and internet addiction

\begin{tabular}{lllllll}
\hline & Frequency & Diagnosis & $\begin{array}{l}\text { Impact on } \\
\text { Life }\end{array}$ & Craving & Motivation & $\begin{array}{l}\text { Total } \\
\text { Score }\end{array}$ \\
\hline Cyberbullying &, $169^{*}$ & $.336^{* *}$ & $.455^{* *}$ & $.252^{* *}$ & $.324^{* *}$ & $.365^{* *}$ \\
Cyber Victimization & .098 & $.269^{* *}$ & $.360^{* *}$ & $.171^{*}$ & $.288^{* *}$ & $.275^{* *}$ \\
\hline
\end{tabular}

$* \mathrm{p}<.05$, two tailed. $* * \mathrm{p}<.01$, two tailed.

\section{Discussion and Conclusion}

Recent research results showed that there is a significant gender difference for both cyberbullying and victimization. Studies found different results in respect to gender and cyberbullying (Tokunaga, 2010). Some of the research in line with these studies showed that males are more likely to be involved in cyberbullying compared to females (Erdur-Baker, 2010; Li, 2006). On the other hand there are some studies found no difference between genders (Hinduja \& Patchin, 2008; Ybarra, Mitchell, Wolak \& Finkelhor, 2006).

Research results showed that there is a positive association between depression, anxiety, somatization, hostility and cyberbullying and victimization in university students' sample. Literature also indicates results that are similar to the findings of the present study. Although depression, anxiety and somatization are greatly mentioned in literature, researches on hostility are rather few.

Hostility is also found to be correlated with cyberbullying and victimization as previous findings showed that it is a predictor of cyberbullying. As one of the components of hostility includes devaluating others, mistrust towards others, desire of hurting others and to see them hurt (Miller, Smith, Turner \& Hallet, 1996), not surprisingly it is associated with bullying behavior. Cyberbullying behavior includes intentional harm toward others (Notar, Padgett \& Roden, 2013). Victimization and bullying correlation (Mishna, Khoury-Kassabri, Gadalla \& Daciuk, 2012) showed that hostility was indirectly associated with cyberbullying via victimization (Yang, 2013).

Besides, self-concept is another variable that positively correlated with both cyberbullying and victimization. Results showed that a higher degree of correlation is found between cyber 
victimization and negative self-concept. Most of the studies investigate self-esteem and its correlation to cyberbullying. On the other hand, previous studies showed that peer victimization and traditional bullying are associated with cyberbullying (Neary \& Joseph, 1994). Similarly, few studies on cyberbullying and self-concept also found that cyberbullying is correlated with low self-concept (Hines, 2011).

Impulsivity and aggression association is well known today. Biological based relation of impulsivity and aggression also proved by DNA and neuroscience studies (Lesch \& Merschdorf, 2000; Seroczynski, Bergeman \& Coccaro, 1999). As a form of aggression cyberbullying and impulsivity relation also shows correlations. Especially some types of cyberbullying are based on impulsive act or perpetrator. One of the sub categories of cyber aggression typology is defined as anonymous, generally impulsive attacks to others as aggression against random victims or random electronic aggression (Pyzalski, 2012). Present study findings showed that there is a positive correlation between impulsivity and cyberbullying. Correspondingly cyber victimization is also correlated with impulsivity. Due to the fact that aggression and bullying behavior are connected, most of the researches concentrate on impulsivity of bullies. Victimization studies, however, also showed that victims also manifest externalizing behaviors like impulsive ones (Li, 2006).

Impulsivity is not only frequently associated with aggression but also one of the main correlates of addictions (Liu \& Potenza, 2010). Besides, research results showed that excessive use of internet is also associated with bullying and victimization. In line with previous studies declaring that internet use is related with cyberbullying, results of this study also showed that internet addiction is another factor that is correlated with cyberbullying and victimization. However, today researches are still trying to find out whether internet use or risky internet use predict cyberbullying and victimization (Erdur-Baker, 2010; Guan \& Subrahmanyam,2009). Internet addiction is considered as one of the possible causes of bullying (Casas, Del Rey \& Ortega-Ruiz, 2013)

Finally yet importantly, empathy is negatively correlated with cyberbullying and victimization. This result is similar to literature findings that mention both cognitive and affective empathy are linked with bullying behavior (Ang \& Goh, 2010; Topçu \& Erdur-Baker, 2012). While researchers showed that empathy is crucial for preventing bullying behavior in bullies (Jolliffe \& Farrington, 2006), empathy and cyberbullying interaction differs from traditional bullying. Several studies emphasized that certain aspects of cyberbullying like anonymity, absence of direct confrontation cause low levels of empathy (Menesini, Nocentini \& Camodeca, 2013; Pornari \& Wood, 2010). Moreover, empathy and moral judgement relation is also an important factor on cyberbullying. Empathy may indirectly play a role on bullying via moral judgement. Internet serves as a moral disinhibition medium which can be called a 'moral disengagement mechanism'. By this mean cyberbullies are less likely to consider their behaviors morally wrong (Perren \& Gutzwiller-Helfenfinger, 2012; Harrison, 2015).

Hostility, impulsivity and empathy are important associating factors of cyberbullying and harming the other. During the last decade, social media and new internet communication channels have become "a vector for youth violence," and created a new space for aggressive behaviors. Young people attempted acts of violence against their peers, such as bullying, harassment, dating aggression, and gang-related crimes. In addition, social media has been used as a vehicle for demonstrating self-harm which is known as cyber-suicide (Patton et al., 2014). Research also shows that youth having aggressive behaviors on social media are more likely to believe that violence against peers is a normative behavior (Hinduja \& Patchin, 2013; Sanders, 2017).

In the book of The Transparency Society, Han (2015) argued that because of new internet communication technologies people became more transparent than ever which is defined as post -privacy society. However author added that the psyche needs spaces that can stand on its own 
from the other's gaze. Otherwise more visibility of it leads to a kind of mental exhaustion. According to author, only the machines are able to have totally transparency. But again, it is claimed that it's not possible to return from the transparency that social media has already created and mankind has to integrate into this new situation in order to keep up with today's society. In this controversial book, author also divided the post privacy society into sub categories such as society of positivity, society of exhibition, society of pornography and society of unveiling. The evaluation regarding society of positivity is essential to understand how social media and internet effect our state of mind and ability to cope with issues. Author stated that positivity society does not allow any negative emotions. Thus, people lose their ability to struggle with troubles and negative situations and get more and more anxious about being unhappy.

To conclude, cyberbullying and victimization are complex structures that are related to various factors. This research results indicate that both bullying and victimization are correlated with anxiety, depression, somatization, hostility, impulsivity, internet addiction and empathy. Research results are found to be in line with the previous studies in this subject area.

Besides there are certain limitations of present research. First, it was conducted with a limited number of students in a small diversity as they study at the same university and are related to each other. As internet users' ages show diversity, future researches may focus on different age groups especially older age groups using the internet and social media. Moreover, statistical analyses of current study are limited with correlation analysis. For a better understanding in terms of the direction of relation, mediator variables should be determined.

Future studies need to be conducted for prevention and intervention because technology age comes with a brand-new understanding and problems. Although cyberbullying and victimization are measured with a standardized inventory, participants' understandings of bullying and being a victim may differ. For that reason, in depth interviews can be useful for better understanding of bullying behavior and what it means for all parties involved. Prevention and intervention programs will be beneficial for future. 


\section{References}

Ahn, D. H. (2007, September). Korean policy on treatment and rehabilitation for adolescents' internet addiction. In 2007 International Symposium on the Counseling and Treatment of Youth Internet Addiction. Seoul, Korea: National Youth Commission, p.49.

Ang, R. P., \& Goh, D. H. (2010). Cyberbullying among adolescents: The role of affective and cognitive empathy, and gender. Child Psychiatry \& Human Development, 41(4), $387-$ 397.

Anzieu, D. (1974). Le moi-peau. Nouvelle revue de psychanalyse, 9(19), 5-208.

Aoyama, I., Saxon, T. F., \& Fearon, D. D. (2011). Internalizing problems among cyberbullying victims and moderator effects of friendship quality. Multicultural Education \& Technology Journal, 5(2), 92-105.

Arıcak, O. T. (2009). Psychiatric symptomatology as a predictor of cyberbullying among university students. Eurasian Journal of Educational Research, 34, 167-184.

Bakken, I. J., Wenzel, H. G., Götestam, K. G., Johansson, A., \& Øren, A. (2009). Internet addiction among Norwegian adults: A stratified probability sample study. Scandinavian Journal of Psychology, 50(2), 121-127.

Barlińska, J., Szuster, A., \& Winiewski, M. (2013). Cyberbullying among adolescent bystanders: Role of the communication medium, form of violence, and empathy. Journal of Community \& Applied Social Psychology, 23(1), 37-51.

Batson, C. D. (2009). These things called empathy: eight related but distinct phenomena. In J. Decety \& W. Ickes (Eds.), The social neuroscience of empathy (3-15). London: The MIT Press.

Bauman, S. (2014). Cyberbullying: What counselors need to know. New York City: John Wiley \& Sons.

Bauman, S., Cross, D., \& Walker, J. L. (Eds.). (2013). Principles of cyberbullying research: Definitions, measures, and methodology. New York: Routledge.

Belsey, B. (2004). Always on, always aware. Retrieved from: Cyberbullying http://www.cyberbullying. ca

Block, J. J. (2008). Issues for DSM-V: Internet addiction. The American Journal of Psychiatry, 165(3), 306-307. doi: https://doi.org/10.1176/appi.ajp.2007.07101556

Bonanno, R. A., \& Hymel, S. (2013). Cyber bullying and internalizing difficulties: Above and beyond the impact of traditional forms of bullying. Journal of Youth and Adolescence, 42(5), 685-697.

Campfield, D. C. (2008). Cyber bullying and victimization: Psychosocial characteristics of bullies, victims, and bully/victims. Unpublished Doctoral Thesis. University of Montana.

Casas, J. A., Del Rey, R., \& Ortega-Ruiz, R. (2013). Bullying and cyberbullying: Convergent and divergent predictor variables. Computers in Human Behavior, 29(3), 580-587.

Cetin, B., Eroglu, Y., Peker, A., Akbaba, S. \& Pepsoy, S. (2012). The investigation of relationship among relational-interdependent self-construal, cyberbullying, and psychological disharmony in adolescents: An investigation of structural equation modelling. Educational Sciences: Theory and Practice, 12(2), 646-653.

Çetin, B., Yaman, E., \& Peker, A. (2011). Cyber victim and bullying scale: A study of validity and reliability. Computers \& Education, 57(4), 2261-2271.

Chang, F. C., Chiu, C. H., Miao, N. F., Chen, P. H., Lee, C. M., Chiang, J. T., \& Pan, Y. C. (2015). The relationship between parental mediation and internet addiction among adolescents, and the association with cyberbullying and depression. Comprehensive Psychiatry, 57, 21-28.

Chen, Y. F., \& Peng, S. S. (2008). University students' internet use and its relationships with academic performance, interpersonal relationships, psychosocial adjustment, and selfevaluation. CyberPsychology \& Behavior, 11(4), 467-469. 
Corcoran, L., Connolly, I \& O'Moore, M. (2012): Cyberbullying in Irish schools: an investigation of personality and self-concept, The Irish Journal of Psychology, 33(4), 153-165, doi:10.1080/03033910.2012.677995

Craig, W. M. (1998). The relationship among bullying, victimization, depression, anxiety, and aggression in elementary school children. Personality and Individual Differences, 24(1), 123-130.

Erdur-Baker, Ö. (2010). Cyberbullying and its correlation to traditional bullying, gender and frequent and risky usage of internet-mediated communication tools. New Media \& Society, 12(1), 109-125.

Erreygers, S., Pabian, S., Vandebosch, H., \& Baillien, E. (2016). Helping behavior among adolescent bystanders of cyberbullying: The role of impulsivity. Learning and Individual Differences, 48, 61-67.

Fanti, K. A., Demetriou, A. G., \& Hawa, V. V. (2012). A longitudinal study of cyberbullying: Examining risk and protective factors. European Journal of Developmental Psychology, 9(2), 168-181.

Farrington, D. P., \& Ttofi, M. M. (2009). School-based programs to reduce bullying and victimization. Campbell Systematic Reviews, 6, 1-149.

Fekkes, M., Pijpers, F. I., \& Verloove-Vanhorick, S. P. (2004). Bullying: Who does what, when and where? Involvement of children, teachers and parents in bullying behavior. Health Education Research, 20(1), 81-91.

Gönül, A. S. (2002).Patolojik İnternet Kullanımı. Yeni Symposium, 40(3), 105-110.

Guan, S. S. A., \& Subrahmanyam, K. (2009). Youth internet use: Risks and opportunities. Current Opinion in Psychiatry, 22(4), 351-356.

Güleç, H., Tamam, L., Turhan, M., Karakuş, G., Zengin, M., \& Stanford, M. S. (2008). Psychometric properties of the Turkish version of the Barratt Impulsiveness Scale11. Klinik Psikofarmakoloji Bülteni, 18(4), 251-258.

Han, B. C. (2015). The transparency society. California: Stanford University Press.

Harrison, T. (2015). Virtuous reality: moral theory and research into cyber-bullying. Ethics and Information Technology, 17(4), 275-283.

Hazler, R. J., Carney, J. V., Green, S., Powell, R., \& Jolly, L. S. (1997). Areas of expert agreement on identification of school bullies and victims. School Psychology International, 18(1), 5-14.

Hinduja, S., \& Patchin, J. W. (2008). Cyberbullying: An exploratory analysis of factors related to offending and victimization. Deviant Behavior, 29(2), 129-156.

Hinduja, S., \& Patchin, J. W. (2010). Bullying, cyberbullying, and suicide. Archives of Suicide Research, 14(3), 206-221.

Hinduja, S., \& Patchin, J. W. (2013). Social influences on cyberbullying behaviors among middle and high school students. Journal of Youth and Adolescence, 42(5), 711-722.

Hines, H. N. (2011). Traditional bullying and cyber-bullying: Are the impacts on self-concept the same? (Doctoral dissertation). Retrieved from http://libres.uncg.edu/ir/wcu/f/Hines2011.pdf

Jolliffe, D., \& Farrington, D. P. (2006). Examining the relationship between low empathy and bullying. Aggressive Behavior, 32(6), 540-550. http://dx.doi.org/ 10.1002/ab.20154.

Katzer, C., Fetchenhauer, D., \& Belschak, F. (2009). Cyberbullying: Who are the victims? A comparison of victimization in internet chatrooms and victimization in school. Journal of Media Psychology, 21(1), 25-36.

Klomek, A. B., Marrocco, F., Kleinman, M., Schonfeld, I. S., \& Gould, M. S. (2007). Bullying, depression, and suicidality in adolescents. Journal of the American Academy of Child \& Adolescent Psychiatry, 46(1), 40-49.

Koh, K. B. (2013). Somatization and psychosomatic symptoms. New York: Springer.

Kowalski, R. M., \& Limber, S. P. (2013). Psychological, physical, and academic correlates of cyberbullying and traditional bullying. Journal of Adolescent Health, 53(1), S13-S20. 
Kowalski, R. M., Giumetti, G. W., Schroeder, A. N., \& Lattanner, M. R. (2014). Bullying in the digital age: A critical review and meta-analysis of cyberbullying research among youth. Psychol Bulletin 140(4):1073-137. doi: 10.1037/a0035618.

Lesch, K. P., \& Merschdorf, U. (2000). Impulsivity, aggression, and serotonin: a molecular psychobiological perspective. Behavioral Sciences \& The Law, 18(5), 581-604.

Li, Q. (2006). Cyberbullying in schools: A research of gender differences. School Psychology International, 27(2), 157-170.

Lianos, H., \& McGrath, A. (2017). Can the general theory of crime and General Strain Theory explain cyberbullying perpetration? Crime \& Delinquency, doi: https://doi.org/10.1177/0011128717714204

Liu, T., \& Potenza, M. N. (2010). Problematic internet use clinical aspects. In E. Aboujaoude \& L. M. Koran (Eds.), Impulse Control Disorders, (167-181) New York: Cambridge University Press.

Martinez-Pecino, R., \& Durán, M. (2016). I love you but I cyberbully you: The role of hostile sexism. Journal of Interpersonal Violence, 1-14. doi: 10.1177/0886260516645817.

McKenna, K. Y., \& Bargh, J. A. (2000). Plan 9 from cyberspace: The implications of the internet for personality and social psychology. Personality and Social Psychology Review, 4(1), 57-75.

Menesini, E., Nocentini, A., \& Camodeca, M. (2013). Morality, values, traditional bullying, and cyberbullying in adolescence. British Journal of Developmental Psychology, 31(1), 1-14.

Miller, T. Q., Smith, T. W., Turner, C. W., Guijarro, M. L., \& Hallet, A. J. (1996). Meta-analytic review of research on hostility and physical health. Psychological Bulletin, 119(2), 322.

Mishna, F., Khoury-Kassabri, M., Gadalla, T., \& Daciuk, J. (2012). Risk factors for involvement in cyber bullying: Victims, bullies and bully-victims. Children and Youth Services Review, 34(1), 63-70.

Na, H., Dancy, B. L., \& Park, C. (2015). College student engaging in cyberbullying victimization: Cognitive appraisals, coping strategies, and psychological adjustments. Archives of Psychiatric Nursing, 29(3), 155-161.

Navarro, R., Serna, C., Martínez, V., \& Ruiz-Oliva, R. (2013). The role of internet use and parental mediation on cyberbullying victimization among Spanish children from rural public schools. European Journal of Psychology of Education, 28(3), 725-745.

Neary, A., \& Joseph, S. (1994). Peer victimization and its relationship to self-concept and depression among schoolgirls. Personality and Individual Differences, 16(1), 183-186.

Nixon, C. L. (2014). Current perspectives: the impact of cyberbullying on adolescent health. Adolescent Health, Medicine and Therapeutics, 5, 143.

Nocentini, A., Calmaestra, J., Schultze-Krumbholz, A., Scheithauer, H., Ortega, R., \& Menesini, E. (2010). Cyberbullying: Labels, behaviours and definition in three European countries. Journal of Psychologists and Counsellors in Schools, 20(2), 129-142.

Notar, C. E., Padgett, S., \& Roden, J. (2013). Cyberbullying: A review of the literature. Universal Journal of Educational Research, 1(1), 1-9.

Ogel, K., Karadag, F., Satgan, D., \& Koc, C. (2015). Development of the Addiction Profile Index Internet Addiction Form (APIINT): Validity and reliability. Düşünen Adam, 28(4), 337.

Pabian, S., \& Vandebosch, H. (2014). Using the theory of planned behaviour to understand cyberbullying: The importance of beliefs for developing interventions. European Journal of Developmental Psychology, 11(4), 463-477.

Patchin, J. W., \& Hinduja, S. (2006). Bullies move beyond the schoolyard: A preliminary look at cyberbullying. Youth Violence and Juvenile Justice, 4(2), 148-169.

Patton, D. U., Hong, J. S., Ranney, M., Patel, S., Kelley, C., Eschmann, R., \& Washington, T. (2014). Social media as a vector for youth violence: A review of the literature. Computers in Human Behavior, 35, 548-553.

Perren, S., \& Gutzwiller-Helfenfinger, E. (2012). Cyberbullying and traditional bullying in adolescence: Differential roles of moral disengagement, moral emotions, and moral values. European Journal of Developmental Psychology, 9(2), 195-209. 
Pornari, C. D., \& Wood, J. (2010). Peer and cyber aggression in secondary school students: The role of moral disengagement, hostile attribution bias, and outcome expectancies. Aggressive Behavior, 36(2), 81-94.

Price, M., Chin, M. A., Higa-McMillan, C., Kim, S., \& Frueh, B. C. (2013). Prevalence and internalizing problems of ethnoracially diverse victims of traditional and cyber bullying. School Mental Health, 5(4), 183-191.

Pyżalski, J. (2012). From cyberbullying to electronic aggression: Typology of the phenomenon. Emotional and Behavioural Difficulties, 17(3-4), 305-317.

Richardson, D. R., Hammock, G. S., Smith, S. M., Gardner, W., \& Signo, M. (1994). Empathy as a cognitive inhibitor of interpersonal aggression. Aggressive Behavior, 20(4), 275-289.

Roy-Byrnr, P. (2004). Anxiety. In Craighead, W. E., \& Nemeroff, C. B. (Eds.), The concise Corsini encyclopedia of psychology and behavioral science. New York City: John Wiley $\&$ Sons.

Sanders, C. E., \& Henry, B. C. (2017). The role of beliefs about aggression in cyberbullying and Animal abuse. Psychology, Crime \& Law, 23(9), 827-840.

Seroczynski, A. D., Bergeman, C. S., \& Coccaro, E. F. (1999). Etiology of the impulsivity/aggression relationship: genes or environment? Psychiatry Research, 86(1), 41-57.

Solberg, M. E., \& Olweus, D. (2003). Prevalence estimation of school bullying with the Olweus Bully/Victim Questionnaire. Aggressive Behavior, 29(3), 239-268.

Spears, B., Slee, P., Owens, L., \& Johnson, B. (2009). Behind the scenes and screens: Insights into the human dimension of covert and cyberbullying. Zeitschrift für Psychologie/Journal of Psychology, 217(4), 189-196.

Strayer, J., \& Roberts, W. (2004). Empathy and Observed Anger and Aggression in Five-Year Olds. Social Development, 13(1), 1-13.

Şahin, N. H., \& Durak, A. (1994). Kisa semptom envanteri (Brief Symptom Invetory-BSI): Türk gencleri icin uyarlanmasi. Türk Psikoloji Dergisi, 9(31), 44-56

Şahin, M., Sarı, S. V., Ömer, Ö. Z. E. R., \& Er, S. H. (2010). Lise öğrencilerinin siber zorba davranışlarda bulunma ve maruz kalma durumlarına ilişkin görüşleri. Süleyman Demirel Üniversitesi Fen-Edebiyat Fakültesi Sosyal Bilimler Dergisi, 21, 257-270

Tarlow, E. M., \& Haaga, D. A. (1996). Negative self-concept: Specificity to depressive symptoms and relation to positive and negative affectivity. Journal of Research in Personality, $30(1), 120-127$.

Tennant, J. E., Demaray, M. K., Coyle, S., \& Malecki, C. K. (2015). The dangers of the web: Cybervictimization, depression, and social support in college students. Computers in Human Behavior, 50, 348-357.

Tokunaga, R. S. (2010). Following you home from school: A critical review and synthesis of research on cyberbullying victimization. Computers in Human Behavior, 26(3), 277-287.

Tomşa, R., Jenaro, C., Campbell, M., \& Neacşu, D. (2013). Student's experiences with traditional bullying and cyberbullying: Findings from a Romanian sample. Procedia-Social and Behavioral Sciences, 78, 586-590.

Topçu, Ç. (2008). The relationship of cyber bullying to empathy, gender, traditional bullying, internet use and adult monitoring. Unpublished Master Dissertation, Middle East Technical University, Ankara.

Topcu, Ç., \& Erdur-Baker, Ö. (2012). Affective and cognitive empathy as mediators of gender differences in cyber and traditional bullying. School Psychology International, 33(5), $550-561$

Topçu, Ç., Baker, Ö. E., \& Aydın, Y. Ç. (2016). Temel empati ölçeği Türkçe uyarlaması: Geçerlik ve güvenirlik çalışması. Türk Psikolojik Danışma ve Rehberlik Dergisi, 4(34), 174-182

Valkenburg, P. M., Peter, J., \& Schouten, A. P. (2006). Friend networking sites and their relationship to adolescents' well-being and social self-esteem. CyberPsychology \& Behavior, 9(5), 584-590. 
van Noorden, T. H., Haselager, G. J., Cillessen, A. H., \& Bukowski, W. M. (2014). Dehumanization in children: The link with moral disengagement in bullying and victimization. Aggressive Behavior, 40(4), 320-328.

Wigderson, S., \& Lynch, M. (2013). Cyber-and traditional peer victimization: Unique relationships with adolescent well-being. Psychology of Violence, 3(4), 297.

Willard, N. E. (2007). Cyberbullying and cyberthreats: Responding to the challenge of online social aggression, threats, and distress. Illinois: Research Press.

Yang, S. C. (2012). Paths to bullying in online gaming: The effects of gender, preference for playing violent games, hostility, and aggressive behavior on bullying. Journal of Educational Computing Research, 47(3), 235-249.

Ybarra, M. L., \& Mitchell, K. J. (2004). Online aggressor/targets, aggressors, and targets: A comparison of associated youth characteristics. Journal of Child Psychology and Psychiatry, 45(7), 1308-1316.

Ybarra, M. L., Espelage, D. L., \& Mitchell, K. J. (2007). The co-occurrence of internet harassment and unwanted sexual solicitation victimization and perpetration: Associations with psychosocial indicators. Journal of Adolescent Health, 41(6), 31-41.

Ybarra, M. L., Mitchell, K. J., Wolak, J., \& Finkelhor, D. (2006). Examining characteristics and associated distress related to internet harassment: Findings from the second youth internet safety survey. Pediatrics, 118(4), 1169-1177.

Young, K. S. (2004). Internet addiction: A new clinical phenomenon and its consequences. American Behavioral Scientist, 48(4), 402-415.

Zezulka, L. A., \& Seigfried-Spellar, K. C. (2016). Differentiating cyberbullies and internet trolls by personality characteristics and self-esteem. Journal of Digital Forensics, Security and Law, 11(3), 7-26. 